\title{
Sun Protection Factor Activity of Black Glutinous Rice Emulgel Extract (Oryza sativa var glutinosa)
}

\author{
Farhamzah1, Anggun Hari Kusumawati ${ }^{1}$, Maulana Yusuf Alkandahri1,*, Himyatul Hidayah', \\ Dani Sujana ${ }^{2}$, Neni Sri Gunarti ${ }^{1}$, Nia Yuniarsih', Sukma Dewi Apriana ${ }^{1}$, Lilis Setianingsih Agustina ${ }^{1}$
}

${ }^{1}$ Faculty of Pharmacy, Buana Perjuangan Karawang University, Karawang, West Java, INDONESIA.

${ }^{2}$ Diploma Program of Pharmacy, Karsa Husada Garut College of Health Sciences, Garut, West Java, INDONESIA.

\begin{abstract}
Background: Recently, emulgel has emerged as a potential hydrophobic drug delivery method. Therefore, this study aims to evaluate the phytochemical content of Oryza sativa extract and develop an emulgel formulation using Carbapol 940 as a gelling agent. Materials and Methods: The emulsion was placed in a gel basis after preparation and the formulations were evaluated for their rheology, $\mathrm{pH}$, spreading coefficient, stability, and sun protection factor. Then, phytochemical analysis of $O$. sativa extract was used to determine the presence of alkaloids, flavonoids, polyphenols, quinones, monoterpenoids, and sesquiterpenoids, as well as triterpenoids and steroids. Results: The entire formulations of $O$. sativa emulgel extract filled the emulgel formulation criteria. Furthermore, $O$. sativa emulgel protects against UV radiation, as indicated by the SPF value in each formulation, which increases as the dose of $O$. sativa extract increases. Based on the results, formulations 2 and 3 have an SPF of $5.71 \pm 0.063$ and $16.07 \pm 0.072$, respectively. These suggest that they both fill the Indonesian National Standard, which requires a sunscreen preparation with a minimum of four protection. Conclusion: Consequently, $O$. sativa emulgel extract can serve as a novel sunscreen agent against UV radiation. However, further study is required to ascertain the mechanism of action of the active chemicals found in $O$. sativa that function as antioxidant and give protection against UV radiation.

Key words: Oryza sativa, Emulgel, Sun Protection Factor, Ultraviolet, Phytochemical compounds.
\end{abstract}

\section{INTRODUCTION}

The skin as the outermost organ of the human body is susceptible to external harmful effects such as UV radiation exposure. ${ }^{1}$ Excessive exposure to UV radiation can have a devastating effect on the skin. Furthermore, sunburn, skin cancer, oxidative stress, and photoaging can all result from this sort of damage, depending on the amount and type of UV radiation and the individual exposed. ${ }^{2}$ The electromagnetic spectrum of ultraviolet radiation is divided into three regions: UVA, which lies between 320 and $400 \mathrm{~nm}$; UVB between 290 and $320 \mathrm{~nm}$; and UVC between 200 and $290 \mathrm{~nm}$. The atmosphere tends to filter UVC radiation before it reaches the ground. Meanwhile, UVB radiation is not entirely filtered by the ozone layer and causes skin damage, however, the UVA radiation penetrates the epidermis and dermis layers, resulting in premature skin aging. Consequently, the majority of products, including lotions, moisturizers, shampoos, creams, and other skin preparations, contain sunscreen, which protects against the damaging effects of UV radiation. The SPF of sunscreen is defined as the ratio of the amount of UV energy required to create a minimum erythema dose (MED) on protected skin and the amount of UV energy required to produce a MED on unprotected skin. ${ }^{3}$ The MED is the shortest time interval or lowest dosage of UV irradiation that produces the least apparent erythema on exposed skin. ${ }^{4}$ The
Submission Date: 01-11-2021; Revision Date: 10-12-2021; Accepted Date: 29-12-2021.

DOI: 10.5530/ijper.56.1.36 Correspondence: Apt. Maulana Yusuf Alkandahri, M. Farm Faculty of Pharmacy, Buana Perjuangan Karawang University, Karawang, West Java, INDONESIA.

E-mail: alkandahri@gmail. com

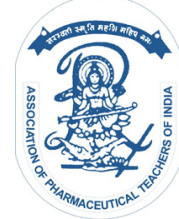

www.ijper.org 
higher the SPF number, the greater the sunscreen's protection against UV rays. However, several studies indicate that using sunscreen to protect the skin from UV radiation is currently not totally. ${ }^{1}$ Hence, it is important to investigate novel sunscreen chemicals produced from natural components. Several studies have demonstrated that natural chemicals are possible sources of sunscreen due to their UV absorption and antioxidant activities. ${ }^{5,6}$ The incorporation of antioxidant chemicals into sunscreens enhances their protective properties against UV radiation and enables the treatment and prevention of UV-induced illnesses. ${ }^{7}$ Indonesia is the world's second most biodiverse country, with 28,000 plant species and an estimated 2,500 plant species with therapeutic qualities, ${ }^{8}$ one of which is Black Glutinous Rice (Oryza sativa). This plant is widely utilized in the production of food and natural sunscreens as well as a cosmetic component such as emulgel. O. sativa extract cannot be applied directly to the skin, therefore, it is transformed into emulgel. One of the benefits of emulgel is that it is a hydrophobic carrier material that cannot be immediately absorbed into the gel foundation. It also aids in the unification of hydrophobic active substances in the oil phase, after which the oil globules are distributed in the water phase $\left(\mathrm{O} / \mathrm{W}\right.$ emulsion) and combined in a gel foundation. ${ }^{9,10}$ Therefore, this study aims to determine the activity of the sun protection factor (SPF) of an emulgel extract from O. sativa.

\section{MATERIALS AND METHODS \\ Plant determination and extraction}

A total of 10 kilograms of fresh O. sativa were collected in Bungur Gede Village, Subang Regency, West Java, Indonesia, and transported to Central Laboratory, Buana Perjuangan Karawang University for cleaning, drying, grinding, and extraction. The plant was recognized as O. sativa by the School of Life Sciences and Technology, Bandung Institute of Technology in West Java. Then, 3 kilograms of $O$. sativa powder were macerated completely in $96 \%$ ethanol forl over $3 \times 24-\mathrm{hr}$. Then, the liquid extract was collected and concentrated at a temperature of $50^{\circ} \mathrm{C}$ using a rotary evaporator (Eyela OSB-2100).

\section{Phytochemical screening}

Qualitative screening of O. sativa extract was performed to determine the presence of secondary metabolites such as alkaloids, flavonoids, terpenoids, phenolic compounds, tannins, saponins, and quinones. ${ }^{11}$

\section{Emulgel preparation}

A variety of emulgel producing agents were used to create the formulation, which begins with the same emulsion preparation. The gel phase was prepared by dispersing HPMC in distilled water and stirred at a speed of $300 \mathrm{rpm}$ with a magnetic heater stirrer (Bioevopeak Co., Ltd., China). Furthermore, carbopol 940 was dissolved in distilled water and then triethanolamine was added to form the aqueous phase of the emulsion (TEA). Afterward, mechanical stirring was used to ensure consistency at a medium pace. The emulsion's oil phase was made by dissolving tween 80 in liquid paraffin. Propylene glycol is dissolved in methylparaben, and then glycerin is added. Then, the oil and water phases were heated separately at $70-80^{\circ} \mathrm{C}$, and the oil phase was introduced to the water with constant stirring until it reaches room temperature. $O$. sativa extract was then dissolved in distilled water and combined with a room temperature combination of water and oil phases, then swirled until homogenous and scent was added. The resulting emulsion was combined with the gel phase at a ratio of 1:1 and then agitated to form an emulsion. ${ }^{12}$ Table 1 contains the composition of the emulgel formulation utilized in the investigation.

\section{Physical examination}

Color, appearance, and the consistency of the produced emulsion compositions were visually evaluated. ${ }^{13}$

\section{Rheological studies}

The viscosity of different emulgel compositions was measured using a cone and plate viscometer equipped with a spindle 7 (Lamy Rheology, France). Afterwards, the assembly is linked to a thermostatically regulated water bath and kept at a temperature of $25^{\circ} \mathrm{C}$. The viscosity-determining formulation is placed in a glass enclosed in a thermostatic jacket and the spindle was let to freely travel within the emulgel. This test was conducted for $10 \mathrm{~min}$ at a speed of $100 \mathrm{rpm} .{ }^{14}$

\section{Measurement of $\mathrm{pH}$}

The $\mathrm{pH}$ of different emulgel formulations was determined using a $\mathrm{pH}$ meter (NeoMet, istek inc, Seoul). The formulation whose $\mathrm{pH}$ is to be determined was placed in a container, the electrode was then inserted and the results were recorded. ${ }^{15}$

\section{Spreading coefficient}

The dispersion coefficient was measured by placing $1 \mathrm{~g}$ of the emulgel formulation on a clear glass lined with graph paper. Then, it was covered by a glass plate with a specified load (5-30 g), and allowed to stand for 


\begin{tabular}{|c|c|c|c|c|}
\hline \multirow[t]{2}{*}{ Ingredient } & \multicolumn{4}{|c|}{ Concentration $(\% w / w)$} \\
\hline & Blank & F1 & F2 & F3 \\
\hline O. sativa extract & - & 0.1 & 0.5 & 1 \\
\hline HPMC & 0.3 & 0.3 & 0.3 & 0.3 \\
\hline Carbopol 940 & 0.3 & 0.3 & 0.3 & 0.3 \\
\hline Triethylnolamin & 0.3 & 0.3 & 0.3 & 0.3 \\
\hline Tween 80 & 0.82 & 0.82 & 0.82 & 0.82 \\
\hline Propylene glycol & 1 & 1 & 1 & 1 \\
\hline Glyserin & 3 & 3 & 3 & 3 \\
\hline Methyl parabene & 0.1 & 0.1 & 0.1 & 0.1 \\
\hline Parfume & 3 drops & 3 drops & 3 drops & 3 drops \\
\hline Aquadestilata & $50 \mathrm{ml}$ & $50 \mathrm{ml}$ & $50 \mathrm{ml}$ & $50 \mathrm{ml}$ \\
\hline
\end{tabular}

$60 \mathrm{sec}$. The area specified by the emulgel formulation was calculated. Greater dispersion coefficients are indicated by shorter distance intervals. ${ }^{16}$

\section{Stability test}

Emulgel samples of $O$. sativa extract were stored at cold $\left(4 \pm{ }^{\circ} \mathrm{C}\right)$, room $\left(27 \pm 2^{\circ} \mathrm{C}\right)$, and hot temperatures $\left(40 \pm 2^{\circ} \mathrm{C}\right)$ for 90 days, and the physical appearance, $\mathrm{pH}$, and viscosity tests on all formulas and all temperatures were observed. ${ }^{17}$

\section{Sun protection factor (SPF) assay}

A total of $5 \mathrm{~g}$ of the emulgel formulation was dissolved with $50 \mathrm{ml}$ of ethanol p.a and filtered. Afterwards, $4 \mathrm{ml}$ of the solution was placed in the cuvette to determine the SPF value using a UV-Vis spectrophotometer (Shimadzu UV Mini-1240) at wavelengths of 290, 295, 300, 305, 310,315 , and $320 \mathrm{~nm}$. The results were compared using ethanol solution as a blank and was repeated 4 times. Then, the SPF value is determined using the Mansur equation as follows. ${ }^{18}$

$$
\text { SPF spectrophotometric }=E F \times \sum_{290}^{320} E E(\lambda) \times 1(\lambda) \times a b s(\lambda)
$$

Where:

$\mathrm{CF}=10$ (correction factor).

$\mathrm{EE} \quad=$ Erythemaous radiation effect spectrum.

I = Sunlight intensity spectrum.

Abs = Absorbance value of sunscreen products.

\section{Data analysis}

The experimental results were expressed as the mean \pm standard deviation (SD) of the four replicates and the data were analyzed using SPSS (version 22). For statistical analysis, a one-way analysis of variance (ANOVA) was used.

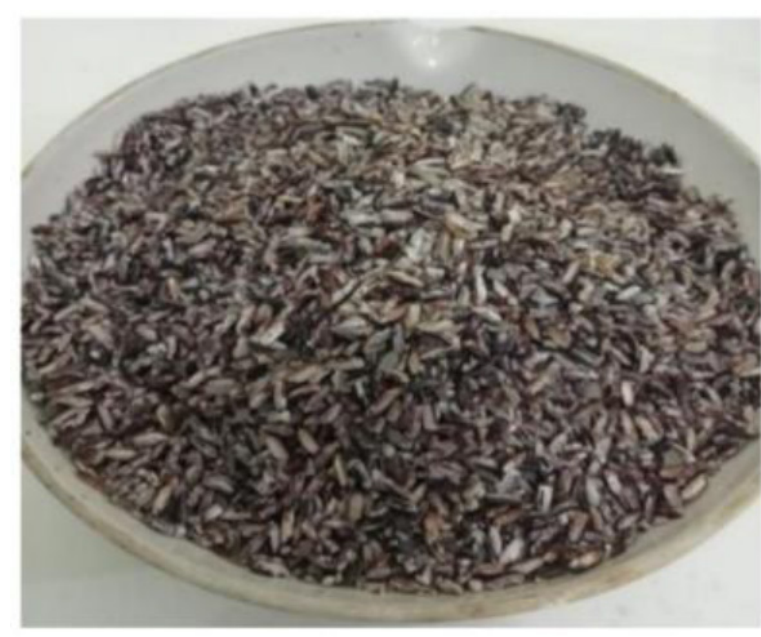

Figure 1: Black glutinous rice (Oryza sativa var. glutinosa).

\section{RESULTS AND DISCUSSION}

\section{Plant determination and extraction of $\boldsymbol{O}$. sativa}

The plant was identified as O. sativa (Figure 1) by the School of Life Sciences and Technology, Bandung Institute of Technology, West Java, Indonesia with No. 6721/11.CO2.2/PI./2019. O. sativa extraction yielded $151.37 \mathrm{~g}(5.05 \%)$ concentrate (fixed weight of extract divided by weight of simplicia multiplied by $100 \%$ ).

\section{Phytochemical screening}

Phytochemical screening of $O$. sativa extract revealed the presence of chemical elements such as alkaloids, flavonoids, polyphenols, quinones, monoterpenoids, sesquiterpenoids, triterpenoids, and steroids (Table 2).

\section{Physical examination}

The prepared emulgel formulations are visually inspected for colour, appearance, and consistency. The results are shown in Table 3 and Figure 2. 


\begin{tabular}{|c|c|c|c|}
\hline Phytochemical compounds & Reagents & Observation & Results \\
\hline \multirow{3}{*}{ Alkaloids } & Dragendorff & (+) Light brown & \multirow{3}{*}{ (+) Alkaloids } \\
\hline & Bouchardat & (+) Dark brown & \\
\hline & Mayer & $\begin{array}{l}\text { (+) Muddy and white } \\
\text { sediment }\end{array}$ & \\
\hline \multirow{2}{*}{ Flavonoids } & $\mathrm{Zn}+\mathrm{HCl}(p)$ & \multirow{2}{*}{$(+)$ Red } & \multirow{2}{*}{ (+) Flavonoids } \\
\hline & $\mathrm{Mg}+\mathrm{HCl}(p)$ & & \\
\hline Polyphenols & $1 \% \mathrm{FeCl}_{3}$ & $(+)$ Dark blue & (+) Polyphenols \\
\hline Tannins & $1 \%$ Gelatin & (-) White sediment & (-) Tannins \\
\hline Quinones & $5 \% \mathrm{KHO}$ & $(+)$ Yellow & (+) Quinones \\
\hline Saponins & Hot water $+\mathrm{HCl}$ & (-) Bubble & (-) Saponins \\
\hline Monoterpenoids and Sesquiterpenoids & Vanillin $+\mathrm{H}_{2} \mathrm{SO}_{4}(\mathrm{p})$ & (+) Pink & $\begin{array}{l}\text { (+) Monoterpenoids and } \\
\text { Sesquiterpenoids }\end{array}$ \\
\hline Triterpenoids and Steroids & Liebermann-Burchard & (+) Purple & (+) Triterpenoids and Steroids \\
\hline
\end{tabular}

$(+)=$ Contained,$(-)=$ Not contained .

\begin{tabular}{|c|c|c|c|}
\hline Formulation & Color & Homogeneity & Consistency \\
\hline F0 & Clear & Excellent & Excellent \\
\hline F1 & Pale brown & Excellent & Excellent \\
\hline $\mathrm{F} 2$ & Light brown & Excellent & Excellent \\
\hline F3 & Brown & Excellent & Excellent \\
\hline
\end{tabular}

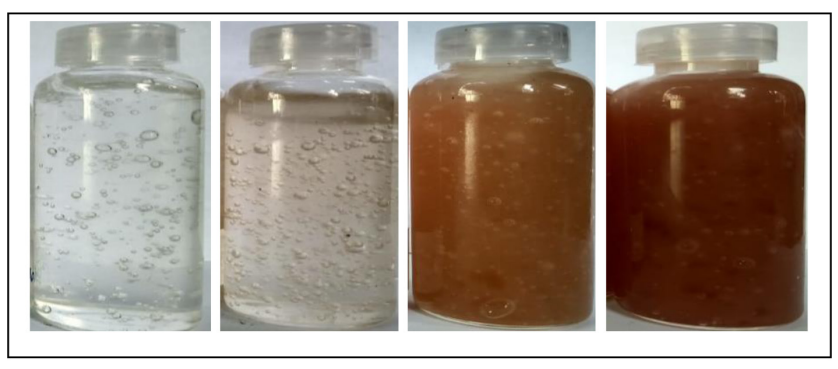

Figure 2: Emulgel formulations of $O$. sativa extract.

\section{Rheological studies}

The results of viscosity testing on all formulations of $O$. sativa emulgel extract showed a change in viscosity in each formulation $(\mathrm{F} 0=4642 \mathrm{cPs}, \mathrm{F} 1=3963 \mathrm{cPs}$, $\mathrm{F} 2=3514 \mathrm{cPs}, \mathrm{F} 3=3463 \mathrm{cPs}$ ), however, the changes were still within the range that filled the requirements. Furthermore, the desired viscosity in the preparation of emulgel is between 2000-4000 cPs. This is due to the ointment-like viscosity possessed by the gel that ensures a longer contact time with the skin. ${ }^{19}$ The results of the rheology studies are shown in Figure 3.

\section{Measurement of $\mathrm{pH}$}

The $\mathrm{pH}$ value of a topical preparation must match the skin $\mathrm{pH}$, which is 4.5-6.5. $\mathrm{pH}$ values that are too acidic

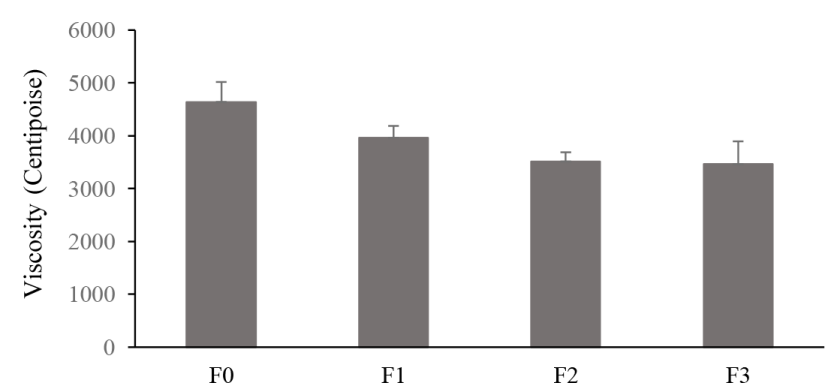

Figure 3: Viscosity of the formulations F0-F3 (mean \pm SD).

result in skin irritation, similarly, too much alkaline causes scaly skin. ${ }^{19}$ The results of $\mathrm{pH}$ measurements in all formulations (F0-F4) using a $\mathrm{pH}$ meter, obtained the average value of 4.52, 4.71, 4.80, and 5.03 for F0, F1, $\mathrm{F} 2$, and $\mathrm{F} 3$, respectively. All formulations fill $\mathrm{pH}$ testing requirements and the results are shown in Figure 4.

\section{Spreading coefficient}

Good dispersion is an indicator that the gel preparation is easy to apply. Therefore, the dispersion test aims to determine the speed of spread and the softness of the emulgel preparation on the skin. The results showed no significant difference in the dispersion value of each formulation $(\mathrm{F} 0=6.0 \mathrm{~cm}, \mathrm{~F} 1=6.2 \mathrm{~cm}, \mathrm{~F} 2=6.7 \mathrm{~cm}$, $\mathrm{F} 3=6.8)$. These indicate that all the formulations filled the dispersion requirements, which are between $5-7 \mathrm{~cm}$ in diameter. ${ }^{20}$ The results are shown in Figure 5.

\section{Stability test}

A stability test was carried out to ensure that the emulgel formulation had the same properties after production as well as filled the criteria parameters during storage. It 


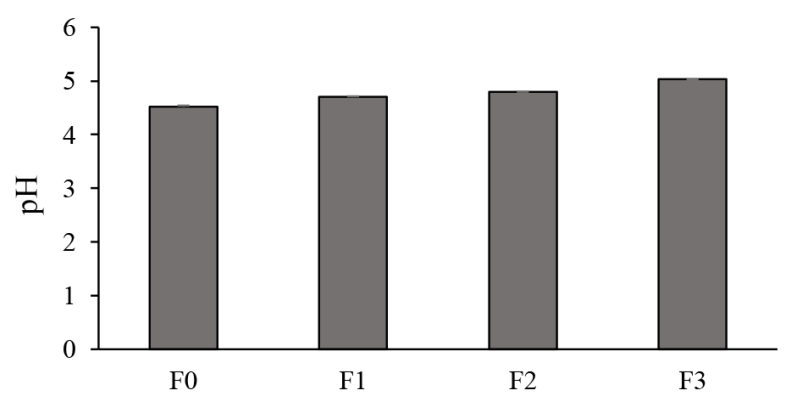

Figure 4: $\mathrm{pH}$ value of the formulations F0-F3 (mean $\pm \mathrm{SD}$ ).

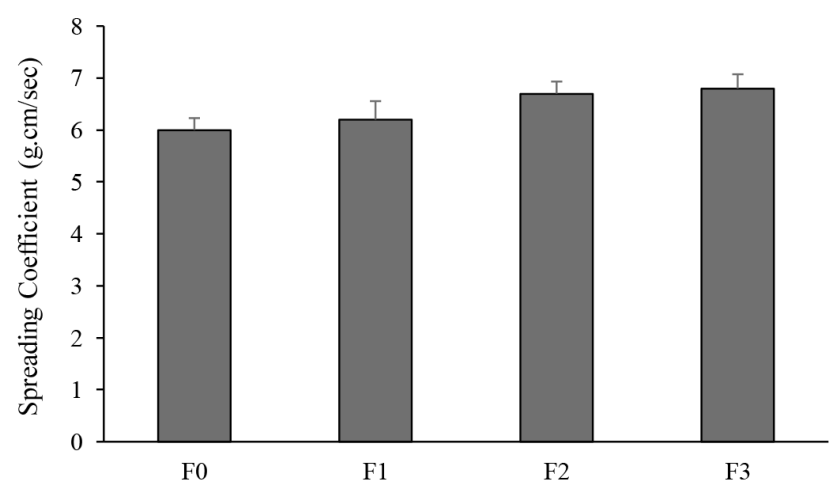

Figure 5: Spreading coefficient of the formulations F0-F3 (mean $\pm \mathrm{SD})$.

also aims to obtain the optimum formulation of O. sativa emulgel extract in a short period by storing the sample in conditions designed to accelerate changes that usually occur under normal conditions. ${ }^{21}$ The results are shown in Table 4.

\section{Sun protection factor (SPF)}

The SPF value is a measure with a higher SPF number indicating greater protection from UV radiation. This SPF rating may be used to determine a sunscreen's efficacy and effectiveness. ${ }^{22}$ The values are shown in Table 5.

The effectiveness of UV protection from $O$. sativa extract emulgel showed differences in each formulation. This was due to the different dosages of $O$. sativa extract from each formulation. The higher the dose in the emulgel formulation, the higher the SPF value. The results show that formulations 2 and 3 are in accordance with the Indonesian National Standard, which states that a sunscreen preparation must have a minimum protection factor of 4 because most Indonesians have skin types IV and V, as such, the recommended SPF used is $5-15 .{ }^{23}$ Furthermore, the protective effect of $O$. sativa emulgel extract against UV is due to its flavonoid compounds, which have protective activity from ultraviolet radiation. ${ }^{1}$ Flavonoid compounds are also known to activate antioxidant enzymes, ${ }^{24-26}$ which protect cells from damage caused by lipid peroxide, ${ }^{27,28}$ reduces alpha-tocopherol radicals, ${ }^{29}$ catalyzes metal chelation and free-electron transfer, ${ }^{30,31}$ inhibits oxidases, ${ }^{32}$ and immunomodulators. ${ }^{33}$ In addition, $O$. sativa extract was also reported to contain several active compounds including anthocyanins, gamma oryzanol, Vitamin E complex, tocotrienols, and $\beta$-sitosterol which can increase the SPF value. ${ }^{34-37}$

The result of an in vitro study showed that a cosmetic formulation containing the anthocyanin (Figure 6) of Purple sweet Potatoes (Ipomoea batatas L.) TNG73, at a concentration of $0.61 \mathrm{mg} / 100 \mathrm{~g}$ cream absorbs up to $46 \%$ of UV radiation exposure. These indicate that the topical use of this type of cosmetic formulation at very low doses helps to prevent UV-induced skin damage by reducing the amount of direct UVB radiation on the epidermis. ${ }^{38}$ Furthermore, various cellular and animal models were used to elucidate the pharmacological mechanisms through which the anthocyanins prevent UV-induced skin damage. A study reported that it was able to prevent damage to human skin structure (EpiD5erm(TM) FT-200) induced by UVB rays. It also protects the skin's ECM by ameliorating UVB-induced overexpression of various MMPs, such as collagenase (MMP-1), gelatinase (MMP-2, MMP-9), stromelysin (MMP-3), matrilysin (MMP- 7), and elastase (MMP12). ${ }^{39}$ These MMPs perform an important physiological role in skin regeneration and cell migration (adhesion/ dispersion). ${ }^{40}$

Other studies also reported that the anthocyanin $\mathrm{C} 3 \mathrm{G}$ inhibits UV-induced translocation of NF-KB and AP-1 and other inflammatory responses in keratinocytes. Consequently, $\mathrm{C} 3 \mathrm{G}$ provides multifaceted protection against skin damage due to $\mathrm{NF-KB}$ and AP-1, which are key modulators of some skin cellular survival programs. These include the synthesis of inflammatory

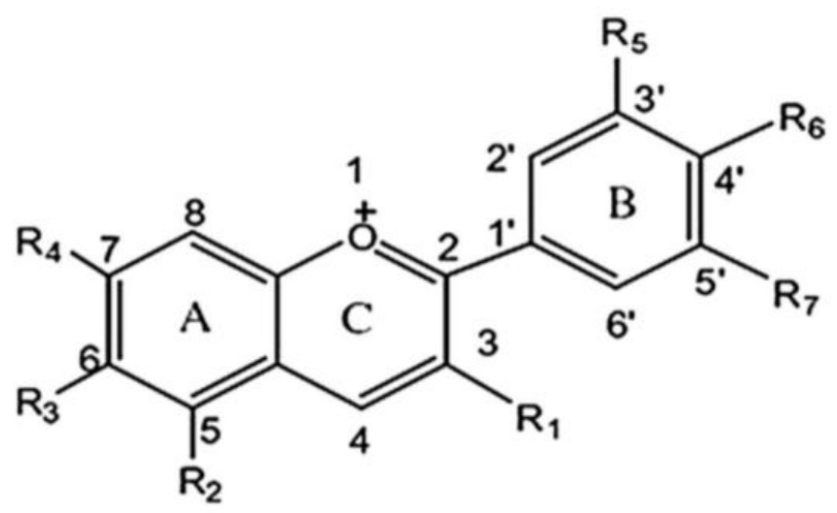

Figure 6: Chemical structure of anthocyanidins. 


\begin{tabular}{|c|c|c|c|c|c|}
\hline \multirow{2}{*}{ Observation Days } & \multirow{2}{*}{ Formulations } & \multicolumn{4}{|c|}{ Physical Observation } \\
\hline & & Color & Homogeneity & Form & Consistency \\
\hline \multirow{4}{*}{1} & F0 & Clear & Excellent & Semi Solid & Excellent \\
\hline & $\mathrm{F} 1$ & Light orange & Excellent & Semi Solid & Excellent \\
\hline & F2 & Light brown & Excellent & Semi Solid & Excellent \\
\hline & F3 & Brownish red & Excellent & Semi Solid & Excellent \\
\hline \multirow{4}{*}{7} & F0 & Clear & Excellent & Semi Solid & Excellent \\
\hline & F1 & Light orange & Excellent & Semi Solid & Excellent \\
\hline & $\mathrm{F} 2$ & Light brown & Excellent & Semi Solid & Excellent \\
\hline & F3 & Brownish red & Excellent & Semi Solid & Excellent \\
\hline \multirow{4}{*}{15} & F0 & Clear & Excellent & Semi Solid & Excellent \\
\hline & $\mathrm{F} 1$ & Light orange & Excellent & Semi Solid & Excellent \\
\hline & $\mathrm{F} 2$ & Light brown & Excellent & Semi Solid & Excellent \\
\hline & F3 & Brownish red & Excellent & Semi Solid & Excellent \\
\hline \multirow{4}{*}{30} & Fo & Clear & Excellent & Semi Solid & Excellent \\
\hline & F1 & Light orange & Excellent & Semi Solid & Excellent \\
\hline & $\mathrm{F} 2$ & Light brown & Excellent & Semi Solid & Excellent \\
\hline & F3 & Brownish red & Excellent & Semi Solid & Excellent \\
\hline \multirow{4}{*}{60} & Fo & Clear & Excellent & Semi Solid & Excellent \\
\hline & F1 & Light orange & Excellent & Semi Solid & Excellent \\
\hline & $\mathrm{F} 2$ & Light brown & Excellent & Semi Solid & Excellent \\
\hline & F3 & Brownish red & Excellent & Semi Solid & Excellent \\
\hline \multirow{4}{*}{90} & Fo & Clear & Excellent & Semi Solid & Excellent \\
\hline & $\mathrm{F} 1$ & Light orange & Excellent & Semi Solid & Excellent \\
\hline & $\mathrm{F} 2$ & Light brown & Excellent & Semi Solid & Excellent \\
\hline & F3 & Brownish red & Excellent & Semi Solid & Excellent \\
\hline \multirow{2}{*}{ pH Parameters } & \multirow{2}{*}{ Observation Days } & \multicolumn{4}{|c|}{ pH Test } \\
\hline & & Fo & F1 & F2 & F3 \\
\hline \multirow{6}{*}{$(4.5-6.5)$} & 1 & 4.55 & 4.67 & 4.99 & 5.03 \\
\hline & 7 & 4.60 & 4.74 & 4.95 & 5.01 \\
\hline & 15 & 4.84 & 4.79 & 4.93 & 5.00 \\
\hline & 30 & 4.88 & 4.90 & 4.91 & 5.01 \\
\hline & 60 & 4.98 & 4.90 & 4.92 & 4.96 \\
\hline & 90 & 4.73 & 4.89 & 4.92 & 4.94 \\
\hline \multirow{2}{*}{ Viscosity Parameters } & \multirow{2}{*}{ Observation Days } & \multicolumn{4}{|c|}{ Viscosity Test } \\
\hline & & Fo & F1 & F2 & F3 \\
\hline \multirow{6}{*}{ (2000-5000 cPs) } & 1 & 2974 & 3963 & 3514 & 3463 \\
\hline & 7 & 3824 & 3914 & 3484 & 3423 \\
\hline & 15 & 3145 & 3844 & 3401 & 3384 \\
\hline & 30 & 3512 & 3534 & 3013 & 2976 \\
\hline & 60 & 3341 & 3213 & 2978 & 2836 \\
\hline & 90 & 2431 & 2980 & 2890 & 2785 \\
\hline
\end{tabular}


Table 5: Category of SPF value effectiveness of O. sativa emulgel extract.

\begin{tabular}{|c|c|c|c|}
\hline No & Formulations & SPF value & Effectiveness \\
\hline 1 & F0 & $2.12 \pm 0.062$ & Have not protection \\
\hline 2 & F1 & $3.13 \pm 0.035$ & Minimum protection \\
\hline 3 & F2 & $5.71 \pm 0.063$ & Medium protection \\
\hline 4 & F3 & $16.07 \pm 0.072$ & Very maximum protection \\
\hline
\end{tabular}

*All the observed values are mean \pm SD $(n=4)$.

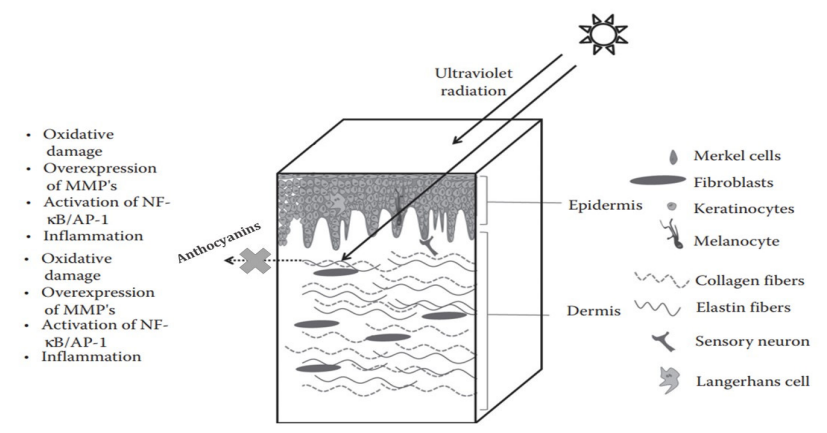

Figure 7: Mechanism of skin protective effect by anthocyanins.

mediators, both innate and adaptive immune effectors. Furthermore, C3G prevents UV-induced overexpression of IL-8, caspase-3 activation, and DNA fragmentation in human keratinocytes. These results suggest that the potential protective role of $\mathrm{C} 3 \mathrm{G}$ is not only against skin damage from accumulative UV but also against psoriasis, which is characterized by hyperactivity of $\mathrm{NF}_{-\mathrm{k}} \mathrm{B}$ in keratinocytes. ${ }^{41}$ It also suggests that anthocyanins may offer protection against photoaging (Figure 7). ${ }^{40}$

\section{CONCLUSION}

This study established that the emulgel formulation of $O$. sativa extracts satisfied the formulation criteria. Furthermore, it exhibits anti-UV activity, as indicated by the SPF value in each formulation, where a higher dose resulted in a higher SPF value. This is also demonstrated by the result, which showed that both formulations 2 and 3 fill the Indonesian National Standard. Consequently, the emulgel of $O$. sativa extract have the potential as a novel sunscreen agent that protects against UV radiation. However, further study is required to ascertain the mechanism of action of the active chemicals found in $O$. sativa that function as an antioxidant and protect against UV radiation.

\section{ACKNOWLEDGEMENT}

This research was carried out with funding from the Ministry of Research, Technology and Higher
Education of the Republic of Indonesia through Penelitian Dosen Pemula No. B/112/E3/RA.00/2021.

\section{CONFLICT OF INTEREST}

The authors declare no conflict of interest.

\section{ABBREVIATIONS}

UV: Ultraviolet; MED: Minimum erythema dose; O/W: Oil/water; HPMC: Hydroxypropyl methylcellulose; TEA: Triethylnolamin; IL: Interleukin; MMP: Metalloproteinases; C3G: Cyanidin-3- O-glucoside; AP-1: Activator protein 1; DNA: Deoxyribonucleic acid; ECM: Extracellular matrix; NF- $\kappa \mathbf{B}$ : Nuclear factor-kappaB.

\section{REFERENCES}

1. Ebrahimzadeh MA, Enayatifard R, Khalili M, Ghaffarloo M, Saeedi M, Yazdani Charati JY. Correlation between sun protection factor and antioxidant activity, phenol and flavonoid contents of some medicinal plants. Iran J Pharm Res. 2014;13(3):1041-47. doi: 10.22037/IJPR.2014.1554, PMID 25276206.

2. Ichihashi M, Ueda M, Budiyanto A, Bito T, Oka M, Fukunaga M, et al. UVinduced skin damage. Toxicology. 2003;189(1-2):21-39. doi: 10.1016/s0300483x(03)00150-1, PMID 12821280.

3. Dutra EA, Oliveira DAGdC, Kedor-Hackmann ERM, Santoro MIRM. Determination of sun protection factor (SPF) of sunscreens by ultraviolet spectrophotometry. Rev Bras Cienc Farm. 2004;40(3):381-85. doi: 10.1590/ S1516-93322004000300014.

4. Wolf R, Wolf D, Morganti P, Ruocco V. Sunscreens. Clin Dermatol. 2001;19(4):452-59. doi: 10.1016/s0738-081x(01)00190-0, PMID 11535388.

5. Liu MC, Lin CT, Shau MD, Chen ZS, Chen MT. Studies on natural ultraviolet absorbers. J Food Drug Anal. 1996;4(4):243-48. doi: 10.38212/22246614.2973

6. Bonina F. Flavonoids as potential protective agents against photo-oxidative skin damage. Int J Pharm. 1996;145(1-2):87-94. doi: 10.1016/S03785173(96)04728-X.

7. F'guyer S, Afaq F, Mukhtar H. Photochemoprevention of skin cancer by botanical agents. Photodermatol Photoimmunol Photomed. 2003;19(2):56-72. doi: 10.1034/j.1600-0781.2003.00019.x, PMID 12945805.

8. Elfahmi, Woerdenbag $\mathrm{HJ}$, Kayser O. Jamu: Indonesian traditional herbal medicine towards rational phytopharmacological use. J Herb Med. 2014;4(2):51-73. doi: 10.1016/j.hermed.2014.01.002.

9. Ajazuddin, Alexander A, Khichariya A, Gupta S, Patel RJ, Giri TK, et al. Recent expansions in an emergent novel drug delivery technology: Emulgel. J Control Release. 2013;171(2):122-32. doi: 10.1016/j.jconrel.2013.06.030, PMID 23831051.

10. Jain A, Gautam SP, Gupta Y, Khambete H, Jain S. Development and characterization of ketoconazole emulgel for topical drug delivery. Pharm Sin. 2010;1(3):221-31.

11. Alkandahri MY, Berbudi A, Utami NV, Subarnas A. Antimalarial activity of extract and fractions of Castanopsis costata (Blume) A.DC. Avicenna J Phytomed. 2019;9(5):474-81. doi: 10.22038/AJP.2019.13188, PMID 31516861.

12. Jain A, Deveda P, Vyas N, Chauhan J, Khambete H, Jain S. Development of antifungal emulsion based gel for topical fungal infection(s). Int J Pharm Res Develop. 2011;2(03):18-25.

13. Kasliwal N, Derle D, Negi J, Gohil J. Effect of permeation enhancers on the release and permeation kinetics of meloxicam gel formulations through rat skin. Asian J Pharm Sci. 2008;3(5):193-99.

14. Bonacucina G, Cespi M, Palmieri GF. Characterization and stability of emulsion gels based on acrylamide/sodium acryloyldimethyl taurate 
copolymer. AAPS PharmSciTech. 2009;10(2):368-75. doi: 10.1208/s12249009-9218-1, PMID 19340587.

15. Kaur LP, Garg R, Gupta GD. Development and evaluation of topical gel of minoxidil from different polymer bases in application of alopecia. Int J Pharm Pharm Sci. 2010;2(3):43-7.

16. Gupta GD, Gaud RS. Release rate of tenoxicam from acrypol gels. Indian Pharm. 2005;4(35):69-76.

17. Butler H. Poucher's parfumes, cosmetics and soaps. 10th ed. Britain: Kluwer Academic Publishers; 2000.

18. Mansur JS, Breder MNR, Mansur MCA, Azulay RD. Determination of sun protection factor for spectrophotometry. An Bras Dermatol. 1986;61:121-4.

19. Garg A, Aggarwal D, Garg S, Sigla AK. Spreading of semisolid formulation: An update. Pharm Technol. 2002;9(2):84-102.

20. Slamet S, Anggun BD, Pambudi DB. Uji Stabilitas Fisik Formula Sediaan Gel Ekstrak Daun Kelor (Moringa oleifera Lamk.). jiks;13(2):115-22. doi: 10.48144/jiks.v13i2.260.

21. Rismayanti AD, Lestari EP, Widayanti S, Handayani R. Uji stabilitas formulasi masker peel off ekstrak etanol batang Sempeng (Nepentes gracilis Korth.). Sultan Agung Fundam Res J. 2021;2(1):1-10.

22. Nash JF, Tanner PR. Sunscreens. In: Cosmetic formulation of skin care products, Cosmetic Science and Technology Series. Vol. 30. Taylor and Francis Group; 2006:136.

23. Sediaan SNI tabir surya. In: Dewan standardisasi nasional; 1996:1-3.

24. Elliott AJ, Scheiber SA, Thomas C, Pardini RS. Inhibition of glutathione reductase by flavonoids. A structure-activity study. Biochem Pharmacol. 1992;44(8):1603-08. doi: 10.1016/0006-2952(92)90478-2, PMID 1329770.

25. Alkandahri MY, Shafirany MZ, Rusdin A, Agustina LS, Pangaribuan F, Fitrianti $\mathrm{F}$, et al. Amomum compactum: A review of pharmacological studies. Plant Cell Biotechnol Mol Biol. 2021;22(33\&34):61-9.

26. Shafirany $M Z$, Indawati I, Sulastri L, Sadino A, Kusumawati $A H$, et al. Antioxidant activity of red and purple rosella flower petals extract (Hibiscus sabdariffa L.). J Pharm Res Int. 2021;33(46B):186-92. doi: 10.9734/jpri/2021/ v33i46B32931.

27. Farombi EO, Fakoya A. Free radical scavenging and antigenotoxic activities of natural phenolic compounds in dried flowers of Hibiscus sabdariffa $\mathrm{L}$ Mol. Mol Nutr Food Res. 2005;49(12):1120-28. doi: 10.1002/mnfr.200500084, PMID 16254885.

28. Sáyago-Ayerdi SG, Arranz S, Serrano J, Goñi I. Dietary fiber content and associated antioxidant compounds in roselle flower (Hibiscus sabdariffa L.) beverage. J Agric Food Chem. 2007;55(19):7886-90. doi: 10.1021/jf070485b, PMID 17705439.

29. Hirano $\mathrm{R}$, Sasamoto $\mathrm{W}$, Matsumoto $\mathrm{A}$, Itakura $\mathrm{H}$, Igarashi $\mathrm{O}$, Kondo $\mathrm{K}$. Antioxidant ability of various flavonoids against DPPH radicals and LDL oxidation. J Nutr Sci Vitaminol (Tokyo). 2001;47(5):357-62. doi: 10.3177/ jnsv.47.357, PMID 11814152.

30. Ferrali M, Signorini C, Caciotti B, Sugherini L, Ciccoli L, Giachetti D, et al. Protection against oxidative damage of erythrocyte membrane by the flavonoid quercetin and its relation to iron chelating activity. FEBS Lett. 1997;416(2):123-29. doi: 10.1016/s0014-5793(97)01182-4, PMID 9369196.

31. Alkandahri MY, Patala R, Pratiwi MI, Agustina LS, Farhamzah KAH, Hidayah H, et al. Pharmacological studies of Durio zibethinus: A medicinal plant review. Ann Rom Soc Cell Biol. 2021;25(4):640-46.

32. Cos P, Ying L, Calomme M, Hu JP, Cimanga K, Van Poel B, et al. Structureactivity relationship and classification of flavonoids as inhibitors of xanthine oxidase and superoxide scavengers. J Nat Prod. 1998;61(1):71-6. doi: 10.1021/np970237h, PMID 9461655.

33. Alkandahri MY, Subarnas A, Berbudi A. Review: Aktivitas immunomodulator tanaman sambiloto (Andrographis paniculata Nees). Farmaka. 2018;16(3):1621. doi: 10.24198/jf.v16i3.14237.

34. Rahim A, Arjuna A, Pakki E, Syaiful SA, Rewa AM, Alam G, et al. Antioxidant and HPTLC study of black glutinous rice extract from south Sulawesi, Indonesia. Int J Pharmacogn Phytochem Res. 2016;8(5):771-76.

35. Chakuton K, Puangpronp D, Nakornriab M. Phytochemical content and antioxidant activity of colored and non-colored Thai rice cultivars. Asian J Plant Sci. 2012;11(6):285-93. doi: 10.3923/ajps.2012.285.293.

36. Saenjum C, Chaiyasut C, Chansakaow S, Suttajit M, Sirithunyalug B. Antioxidant and anti-inflammatory activities of gamma-oryzanol rich extracts from Thai purple rice bran. J Med Plants Res. 2012;6(6):1070-77. doi: 10.5897/JMPR11.1247.

37. Yodmanee S, Karrila TT, Pakdeechanuan P. Physical, chemical and antioxidant properties of pigmented rice grown in Southern Thailand. Int Food Res J. 2011;18(3):901-06.

38. Chan CF, Lien CY, Lai YC, Huang CL, Liao WC. Influence of purple sweet potato extracts on the UV absorption properties of a cosmetic cream. J Cosmet Sci. 2010;61(5):333-41. PMID 20939973.

39. Afaq F, Zaid MA, Khan N, Dreher M, Mukhtar H. Protective effect of pomegranate-derived products on UVB-mediated damage in human reconstituted skin. Exp Dermatol. 2009;18(6):553-61. doi: 10.1111/j.16000625.2008.00829.x, PMID 19320737.

40. Rojo LE, Roopchand D, Graf B, Cheng DM. Role of anthocyanins in skin aging and UV induced skin damage. In: book: Anthocyanins in Health and Disease. Publisher. 1st ed. CRC Press; 2013. p. 307-16.

41. Cimino F, Ambra R, Canali R, Saija A, Virgili F. Effect of cyanidin-3-Oglucoside on UVB-induced response in human keratinocytes. J Agric Food Chem. 2006;54(11):4041-47. doi: 10.1021/jf060253x, PMID 16719532.

\section{PICTORIAL ABSTRACT}

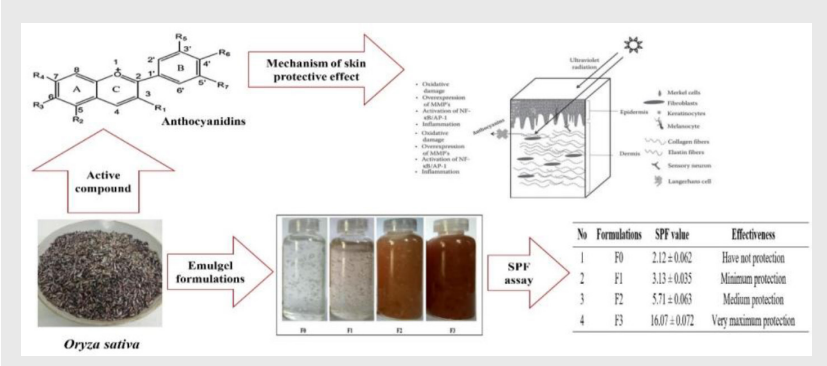

SUMMARY

In this study, we formulated O. sativa into an emulgel extract preparation and evaluated the preparation with various parameters including physical examination, rheological studies, measurement of $\mathrm{pH}$, spreading coefficient and stability test. As a result, all formulations of $O$. sativa emulgel extract met the criteria for emulgel formulations. In addition, we also tested the activity of sun protection factor (SPF) for all formulations of O. sativa emulgel extract. As a result, the higher the dose of the extract, the higher the SPF value in the formulations of the $O$. sativa emulgel extract. 


\section{About Authors}

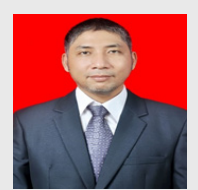

Farhamzah: He is a pharmacist, lecturer and researcher at the Faculty of Pharmacy, Buana Perjuangan Karawang University, Karawang, West Java, Indonesia. Currently, he is focused on conducting research about formulation and physical evaluation of Beluntas plants (Pluchea indica (L.) Less).

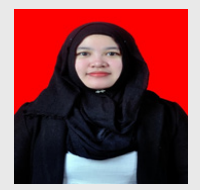

Anggun Hari Kusumawati: She is a pharmacist, lecturer and researcher at the Faculty of Pharmacy, Buana Perjuangan Karawang University, Karawang, West Java, Indonesia. Her research is focusing on nanotechnology of Black Rice (Oryza sativa var. glutinosa) extracts for nutraceutical products.

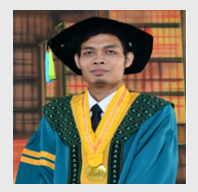

Maulana Yusuf Alkandahri: $\mathrm{He}$ is a pharmacist, lecturer and researcher at the Faculty of Pharmacy, Buana Perjuangan Karawang University, Karawang, West Java, Indonesia. Currently, he is focused on conducting research on local Indonesian medicinal plants that have pharmacological activity.

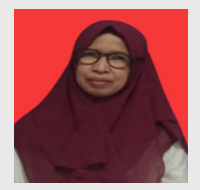

Himyatul Hidayah: She is a pharmacist, lecturer and researcher at the Faculty of Pharmacy, Buana Perjuangan Karawang University, Karawang, West Java, Indonesia. Her research is focusing on the search for active compounds contained in Asteraceae plants.

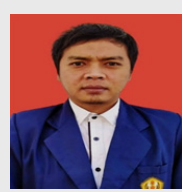

Dani Sujana: He is a pharmacist, lecturer and researcher at the Diploma Program of Pharmacy, Karsa Husada Garut College of Health Sciences, Garut, West Java, Indonesia. Research interests are pharmacological activity, especially from natural product.

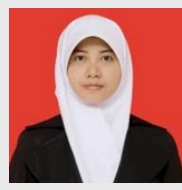

Neni Sri Gunarti: She is a pharmacist, lecturer and researcher at the Faculty of Pharmacy, Buana Perjuangan Karawang University, Karawang, West Java, Indonesia. Her research is focusing on ethnopharmaceutical and bioprospecting of medicinal plants in Karawang Regency.

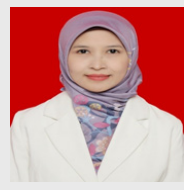

Nia Yuniarsih: She is a pharmacist, lecturer and researcher at the Faculty of Pharmacy, Buana Perjuangan Karawang University, Karawang, West Java, Indonesia. Her research is focusing on formulation and physical evaluation of Kepok Banana (Musa paradisiaca L.).

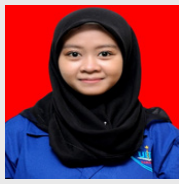

Sukma Dewi Apriana: She is an undergraduate student at the Faculty of Pharmacy, Buana Perjuangan Karawang University, Karawang, West Java, Indonesia.

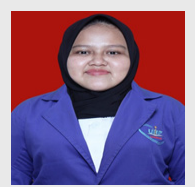

Lilis Setianingsih Agustina: She is an undergraduate student at the Faculty of Pharmacy, Buana Perjuangan Karawang University, Karawang, West Java, Indonesia.

Cite this article: Farhamzah, Kusumawati AH, Alkandahri MY, Hidayah H, Sujana D, Gunarti NS, Yuniarsih N Apriana SD, Agustina LS. Sun Protection Factor Activity of Black Glutinous Rice Emulgel Extract (Oryza sativa var glutinosa. Indian J of Pharmaceutical Education and Research. 2022;56(1):302-10. 